\title{
On the Flotation of a Low Grade Chromite Ore
}

\author{
Tamam T. A. K ${ }^{1}$, Ahmed A.S.Seifelnasr ${ }^{2}$
}

\begin{abstract}
This study is concerned with the processing of low grade chromite ores, Ingassena Hills by froth flotation techniques. For this purpose, representative samples were taken from four different mines. Mineralogical examinations indicated that, the major minerals are chromite and serpentine .Olivine, iron oxides and talc have been identified as minor minerals. Adequate degree of liberation of chromite was obtained by grinding the ore to minus $177 \mu \mathrm{m}$.

Froth flotation was used to upgrade that particular chromite ore. Oleic acid was used as collector. Several operating parameters influencing the floatability of both high grade chromite and serpentine were investigated. These include the concentrations of the collector and depressant, pulp pH and conditioning time. From an ore feed grading $20.27 \% \mathrm{Cr}_{2} \mathrm{O}_{3}$, a chromite concentrate of $28.71 \% \mathrm{Cr}_{2} \mathrm{O}_{3}$ with recovery of $94.54 \%$ could be obtained by flotation at collector dosage of $0.300 \mathrm{~kg} / \mathrm{t}$, neutral pulp (pH 9), conditioning time ,2min ,and pulp density, $20 \%$.
\end{abstract}

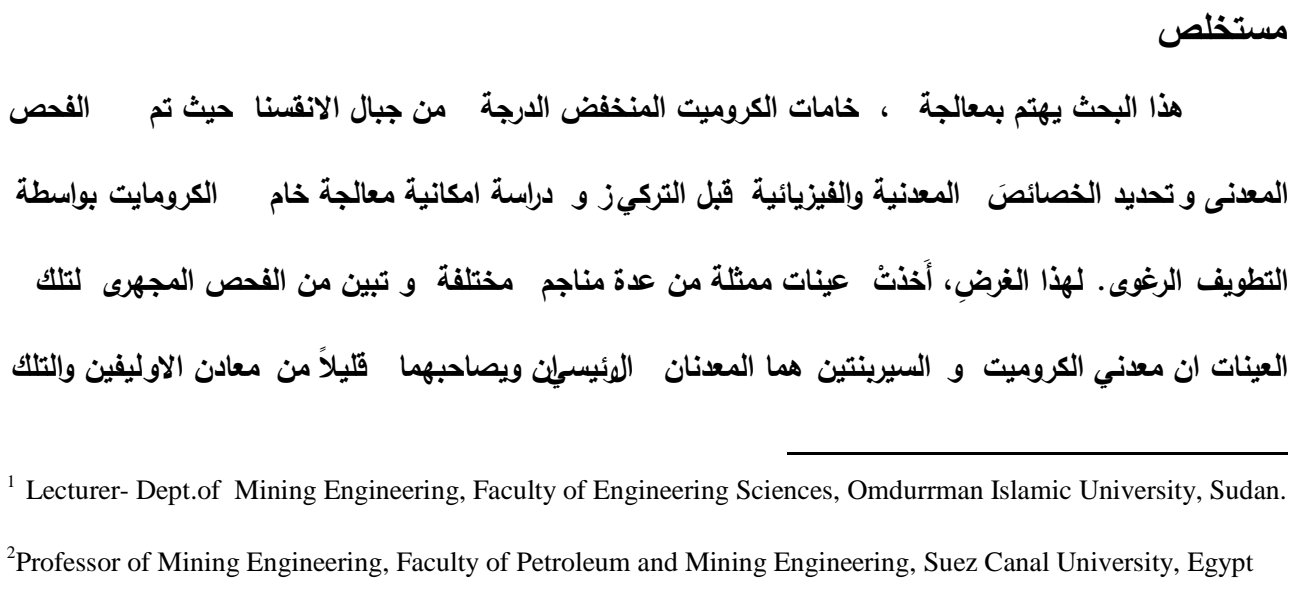




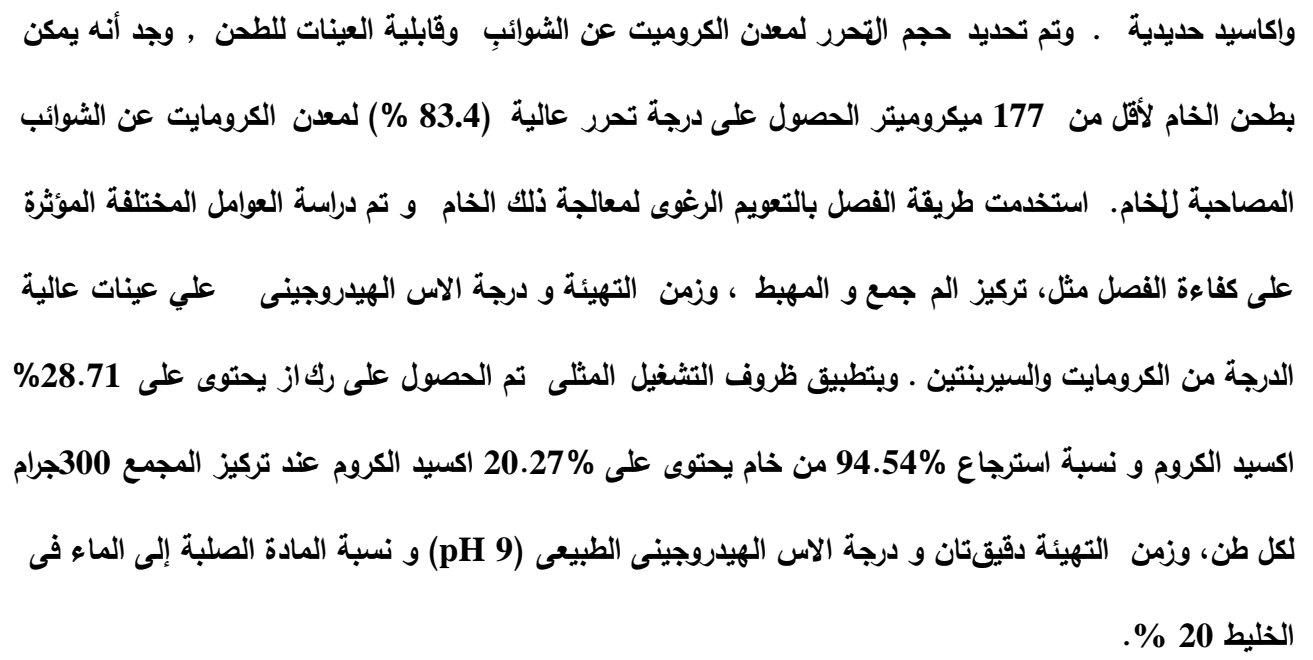

\section{Introduction}

Chromium is one of the most versatile and widely used elements. Its main uses are in the metallurgical, chemical, and refractory industries are well known. Chromium is an essential element in the production of a wide variety of stainless steels, tool and alloy steels, nickel-chromium heating elements, and plating metals. Its widespread use in the metallurgical industry is attributed to its capability of enhancing properties such as resistance to corrosion or oxidation, creep and impact strengths, and hard inability.

In the Sudan, Chromite ore deposits occur in the Ingassana hills in the Blue Nile region and other occurrences had been reported at Hamissana-sol Hamed in the northern Red Sea Hills, the Nuba Mountains in southern Kordofan, J.Rahib northwest Sudan and J.El Tawil in central Butana in southern Sudan. However, the Ingassana chromite ore is considered as one of largest chromite ore deposits in Sudan. 
Low-grade deposits and the fines resulting in the mining operations can not be exported and are unmarketable. Therefore, beneficiation of low grade and fine disseminated ores is becoming more important in recent years due to the shortage of high grade ore reserves. Although gravity methods are well known and widely used for the concentration of chromites, such techniques fail to recover the size fractions below approximately 100 $\mu \mathrm{m}$. Recovery from the fine size fractions is particularly important in finely disseminated ores.

Flotation offers an alternative concentration process for the separation of the fine materials and the avoidance of chromium losses. In general, earlier results of flotation of lower-grade chromite ores were inferior to those obtained by tabling [Ralph H. Nafziger, 1982]. There are two general types of methods for separating chromium ore (chromite) values from associated gangue minerals by froth flotation techniques. In the first method chromite ore which has been deslimed is subjected to flotation at a $\mathrm{pH}$ of 1.5 to 5.5 with a long chain fatty acid collector as reported by Havens, R., 1946. The selectivity of the process is enhanced by the inclusion of a soluble fluoride ion containing compound such as hydrofluoric acid, sodium fluoride or sodium silicofluoride in the flotation medium.

The flotation process is typically conducted by adding 0.5 to 5.0 pounds fatty acid, 0.1 to 10.0 pounds soluble fluoride ion and 1.0 to 11.0 pounds sulfuric acid per ton of ore to the aqueous treatment medium containing the chromite ore. A typical product obtained by such a process from an ore containing $25.2 \% \mathrm{Cr}_{2} \mathrm{O}_{3}$ is a recleaner concentrate containing $41.0 \% \mathrm{Cr}_{2} \mathrm{O}_{3}$ and $2.5 \% \mathrm{SiO}_{2}$ with a chromium recovery of $77.0 \%$. In the 
second technique as shown in [U.S. Pat. No. 3,473,656] chromite ore flotation is achieved with an undeslimed ore at a $\mathrm{pH}$ of 11.5 using a long chain fatty acid collector. The $\mathrm{pH}$ of the pulp is adjusted with $\mathrm{NaOH}$ with the pulp being dispersed by sodium silicate using carboxymethylcellulose as a flocculating depressant for silicate gangue minerals. Typically during processing, three pounds of sodium silicate, from 1.0 to 3.0 pounds of tall oil and from 0.25 to 0.50 pounds of carboxymethylcellulose per ton of ore, are added to a processing solution.

From an ore containing $18.13 \% \mathrm{Cr}_{2} \mathrm{O}_{3}$ and $23.98 \% \mathrm{SiO}_{2}$, a flotation concentrate was obtained containing $52.16 \% \mathrm{Cr}_{2} \mathrm{O}_{3}$ and $3.72 \% \mathrm{SiO}_{2}$ with a chromium recovery of $80.0 \%$. Also, L. Wenz, (1955 cited in E. J. Poyor, 1965) reported studies on a Turkish ore containing $30 \% \mathrm{Cr}_{2} \mathrm{O}_{3}$, associated with oxide and sulphides and gangue minerals are chiefly serpentine and olivine. When grounded to- $100 \mu \mathrm{m}$ the serpentine dominated the fines, chromite the medium particles and olivine the coarse. Strongly alkaline pulp $(\mathrm{pH}+10)$ was used, with sodium oleate and oleic acid (lb/ton) to float the serpentine. The pulp was then rendered acid ( $\mathrm{pH} 3)$ and chromite was floated with.3/4lb./ton of fatty acid-amine collector. Olivine, which only floats in a neutral solution under these conditions, remained in the final tailing, the concentrate grade being $45 \% \mathrm{Cr}_{2} \mathrm{O}_{3}$.

Further studies by the U.S. Bureau of Mines showed that lower-grade chromites could be selectively concentrated by flotation in the presence of slimes.

Preconditioning with fuel oil permitted flotation of the chromite from the flocculated siliceous-gangue slimes. Recoveries of up to 91 per cent 
were realized with products containing up to 45 per cent $\mathrm{Cr}_{2} \mathrm{O}_{3}$ by mass [Hunter, and Sullivan, 1960]. The $\mathrm{Cr} / \mathrm{Fe}$ ratios ranged from 2.17 to 2.46. Oleic acid was used for flotation.

Sodium fluoride and sulphuric acid yielded better results than dilute hydrofluoric acid when these reagents were added to free the 'flocs' from the siliceous gangue. A process developed for one ore does not usually yield optimum results for another ore of different origin. It is thought that differences in the composition of the gangue materials, as well as in the composition of the chromium spinels, are responsible for these variations in flotation behavior.

Fundamental research is required to alleviate this problem. Investigations involving the flotation of a pure chromite and a pure serpentine using sodium oleate as the collector showed [Sagheer, 1966] that the chromite can be collected at collector concentrations of between 0.3 and $1000 \mathrm{mg} / \mathrm{I}$.

\section{Experimental}

\subsection{Materials}

\subsubsection{Chromite Ore Sample}

A chromite ore sample about ( $250 \mathrm{kgs})$ of low grade ore was collected from Chickay mines, at the Ingassana Hills. A high grade chromite ore samples $(10 \mathrm{Kg})$ and a similar pure serpentine sample were selectively collected to investigate their flotation characteristics. Lumpy Samples, about $10 \mathrm{~kg}$ low grade chromite ore were taken from chickay and Romallic mines. Firstly, thin and polish sections have been made for mineralogical analysis. 


\subsection{Methods}

\subsubsection{Preparation of Samples}

The low grade sample (20 kg) was crushed though Jaw crusher and Roll crusher, coned, quartered and divided into lots of $1 \mathrm{~kg}$ samples for the mineralogical and chemical analysis. Table 1 shows the results of the chemical analysis.

Table (1): Results of Chemical Analysis of a chromite Ore Sample (By

\begin{tabular}{|c|c|c|c|c|c|c|c|c|c|}
\hline Loc. & $\mathbf{C a O} \%$ & $\mathbf{M g O} \%$ & $\mathbf{F e} \%$ & $\mathbf{C r}_{\mathbf{2}} \mathbf{O}_{\mathbf{3}}$ & $\mathbf{S i O}_{\mathbf{2}}$ & $\mathbf{A l}_{\mathbf{2}} \mathbf{O}_{\mathbf{3}}$ & L.O.I & $\mathbf{S \%}$ & $\mathbf{C r} / \mathbf{F e}$ \\
\hline $\mathrm{Ch}$. & 0.022 & 13.08 & 6.00 & 24.89 & 24.177 & $\mathrm{ND}$ & 7.33 & $\mathrm{ND}$ & 2.9 \\
\hline $\mathrm{Ro}_{143}$ & 0.034 & 13.56 & 5.80 & 24.31 & 14.108 & $\mathrm{ND}$ & 17.79 & $\mathrm{ND}$ & 2.5 \\
\hline
\end{tabular}

\subsubsection{Characterization of Single High Grade Minerals}

Both the chromite and serpentine samples were obtained from the Gam Chromite Mine, Ingassana hills, Sudan. Chromite and serpentine samples were purified by hand sorting, magnetic separation and panning, washed with triple distilled water. After drying, the sample was ground to pass $250 \mu \mathrm{m}$ sieve by an agar mortar. Density of chromite and serpentine were determined to be 4.6 and $2.6 \mathrm{~g} / \mathrm{cm}^{2}$, respectively.

The ground samples were kept in plastic bags for experiments. The size, chemical and mineralogical compositions of the samples, determined by chemical analysis and microscope methods, are given in table (2). 
مجلة العلوم الهندسيةـ العددالسادس - 2012

Table (2): Chemical, Physical and Mineralogical Properties of High Grade of Chromite and Serpentine Samples

\begin{tabular}{|c|c|c|}
\hline Property & Chromite & Serpentine \\
\hline$\% 100$ passing size, $\mu \mathrm{m}$ & 250 & 250 \\
\hline Specific gravity & 4.6 & 1.2 \\
\hline $\mathrm{Cr}_{2} \mathrm{O}_{3}, \%$ & 57.6 & 12 \\
\hline $\mathrm{Fe}_{2} \mathrm{O}_{3}, \%$ & 19 & 47 \\
\hline $\mathrm{SiO}_{2}, \%$ & 3 & 29 \\
\hline $\mathrm{MgO}, \%$ & 8.5 & 2.5 \\
\hline $\mathrm{CaO}, \%$ & 0.2 & $\begin{array}{r}\text { Serpentine, chlorite, smectite, } \\
\text { hematite, calcite }\end{array}$ \\
\hline Mineralogical & Chromite, hematite, \\
composition & magnetite, olivine & . \\
\hline
\end{tabular}

\subsubsection{Mineralogical and Chemical Properties}

The mineralogical properties of ore sample were examined by ore microscopy, while chemical analysis was conducted by wet chemical assaying methods, AAS, and XRF.

\subsubsection{Liberation Characteristics Study}

The liberation characteristics between chromite and associated gangue was performed as follows; the particles of both chromite and serpentine minerals as well as the locked particles were counted under microscope.

Degree of liberation $=\frac{\text { Liberated } \quad \text { Particals }}{\text { All Particals }} X 100$ 


\subsubsection{Ore Sample Preparation for Final Tests}

Low grade Sample was prepared for flotation tests by stage crushing and grinding down to liberation size $(0.177 \mathrm{~mm}$ particle size $)$. The ground sample was subjected for sieve analysis as show in table (3).

Table (3): Particle -Size Distribution of Chromite Ore as Feed for Flotation

\begin{tabular}{|c|c|c|c|}
\hline Particle size(mm) & Weight\% & Cum.O.size \% & Cum.U.size \% \\
\hline$-0.177+0.076$ & 41.42 & $\mathbf{0}$ & 100 \\
\hline$-0.076+0.038$ & 13.7 & 41.42 & 58.58 \\
\hline-0.038 & 44.9 & 55.1 & 44.9 \\
\hline Total & 100 & -- & -- \\
\hline
\end{tabular}

\subsubsection{Flotation Tests}

For each test, a certain weight of ore sample (chromite / serpentine / chromite ore) was transferred to the flotation cell, then a measured quantity of tap water according to the required pulp density was added. The sample was wetted for 5 minutes, and then the pulp pH was adjusted by $\mathrm{H}_{2} \mathrm{SO}_{4}$ or $\mathrm{NaOH}$. Then the depressant (sodium silicate) dosage was added if required and conditioned for preset period. The collector (oleic acid) dosage was then added and conditioned afterwards, and then the frother was added and conditioned, for 1 minute. Finally the air is open and the froth was collected until the froth is barren. Both froth and the sediment were filtered, dried, weighted and analyzed. 


\section{Results and Discussion}

\subsection{Mineralogical Characteristics}

The examination of Thin and polished sections revealed that the main minerals were chromite $\left[(\mathrm{Fe}, \mathrm{Mg}) \mathrm{O} .(\mathrm{Al}, \mathrm{Fe}, \mathrm{Cr})_{2} \mathrm{O}_{3}\right], \quad$ Serpentine $\left[(\mathrm{Mg}, \mathrm{Fe})_{3} \mathrm{Si}_{2} \mathrm{O}_{5}(\mathrm{OH})_{4}\right]$, talc $\left[\mathrm{Mg}_{3} \mathrm{Si}_{4} \mathrm{O}_{10}(\mathrm{OH})_{2}\right]$, and chlorite. Intercrystaline enhedrall and subhedrall chromite crystals are filled with unhedrall and frequently fractured serpentine crystals (Figure (1)). Traces of olivine can be determined as fine grains within the serpentinite matrix as well as trace quantities of iron oxides, antigorite $(\mathrm{Mg}, \mathrm{Fe})_{3} \mathrm{Si}_{2} \mathrm{O}_{5}(\mathrm{OH})_{4}$, asbestos and talccarbonate .These micrographs gave also the grain size of the these components.

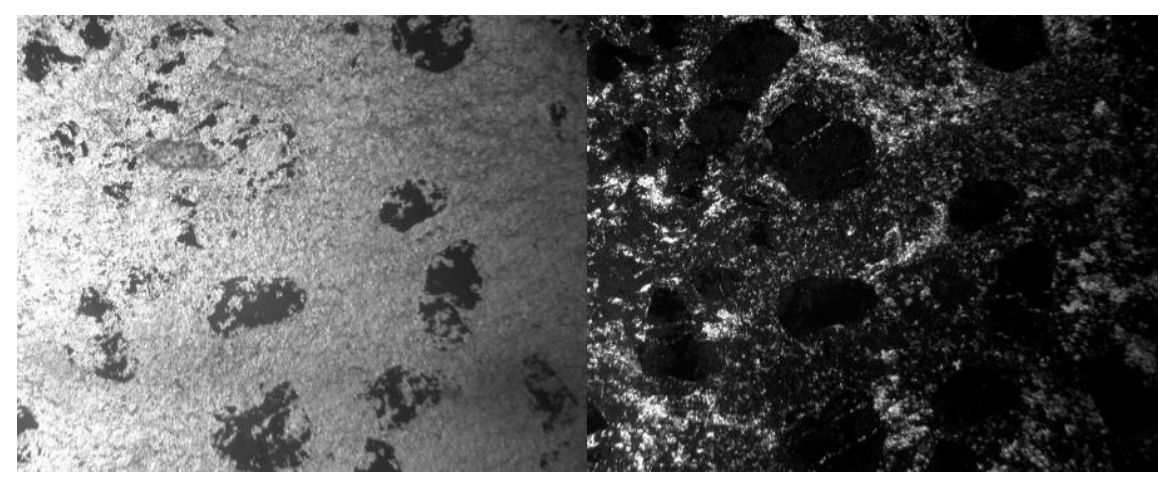

Figure (1): Highly Disseminated and Refractory Chromite. The Chromite Crystals were Subjected to Restoration and Dislocation in a Serpentine Ground Mass Thin Section (XN, 4x10)

The results revealed from investigation of thin and polish sections and chemical analysis, indicated that the ore contains approximately $45 \%-72 \%$ of serpentine, $26 \%$ - $40 \%$ of chromite and traces of talc, olivine, asbestos and iron oxides. Grain size range from 1 to $0.02 \mathrm{~mm}$. 


\subsection{Flotation characteristics of high grade chromite}

Figure (2) shows the chromite flotation recoveries as a function of various concentration of oleic acid at different $\mathrm{pH}$ values. The flotation results revealed that increasing the oleic acid concentration up to $3 \mathrm{~kg} / \mathrm{t}$ causes higher recovery. Because the $\mathrm{pH}$ of the medium is an important factor in flotation, its effect was investigated. The higher flotation recoveries were attained at $\mathrm{pH} \mathrm{9;11,} \mathrm{and} \mathrm{this} \mathrm{may} \mathrm{be} \mathrm{due} \mathrm{that} \mathrm{ions} \mathrm{Al}^{3+}$ and $\mathrm{RCOO}^{-}$ were predominant in the solution [Sobieraj,. and Laskowski, , 1973; Shibata and Fuerstenau, 2003].

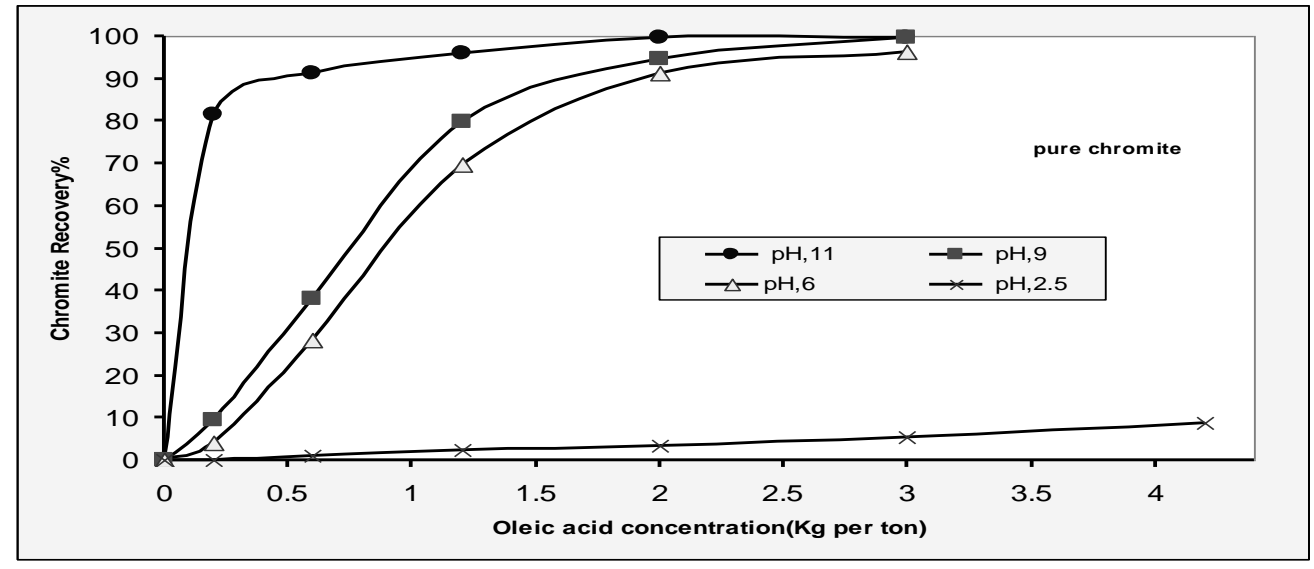

Figure (2): Flotation recoveries of chromite as a function of various concentrations of oleic acid at pH 11; pH 9; pH 2.5

The flotation of a high grade chromite using oleic acid as the collector showed, that the chromite can be collected at collector concentrations of between 0.2 and $2 \mathrm{~kg} / \mathrm{t}$. 


\subsection{Flotation of Serpentine}

Fig. 3 shows the serpentine flotation recoveries as a function of various concentration of oleic acid at $\mathrm{pH} 2.5 ; 6 ; 9 ; 11$. The flotation results revealed that increasing the oleic acid concentration increase of serpentine floatability. The effect of medium $\mathrm{pH}$ was also investigated. The results of which are represented in Fig.3. The maximum flotation recovery using oleic acid was $94.6 \%$, which obtained at $\mathrm{pH} 11$ when $\mathrm{Al}^{3+}$ and $\mathrm{RCOO}^{-}$are predominant in the solution. The flotation recovery using oleic acid was $59.7 \%$, which obtained at $\mathrm{pH}$ 9. Flotation results show that the recovery increased with increasing collector concentration. From the above results it is clear that, both chromite and serpentine minerals have similar flotation characteristics.

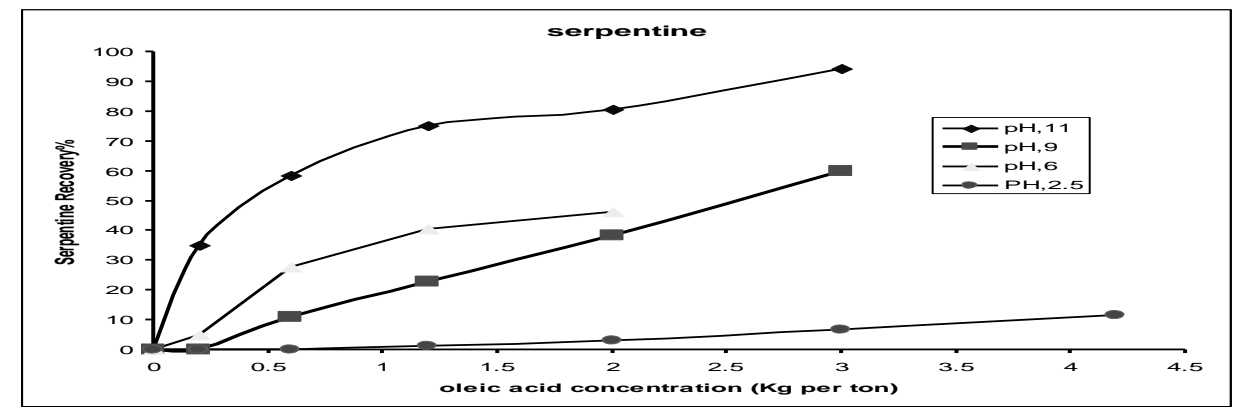

Figure (3): Flotation Recoveries of Serpentine as a Function of Various Concentrations of Oleic Acid at pH 11; pH 9; pH 6; pH 2.5.

\subsection{Influence of pH}

As shown in fig.4, chromite float will in the presence of $200 \mathrm{~g} / \mathrm{t}$ oleic acid at $\mathrm{pH}$ region greater than 10. Fig.5 reveals that chromite float well at $\mathrm{pH}$ greater than $\mathrm{pH}_{\mathrm{pzc}}$, (PH 7 to 9.5) [Palmer B. R., Fuerstenau M.C., Aplan F.F., 1975.]; this considered an evidence of the flotation by chemisorption. 
The decrease of flotation recovery in the acidic $\mathrm{pH}$ range was attributed to adsorption of less surface active oleic acid (neutral acid, HOL (aq) [Somasundaran and Wang, 2006].

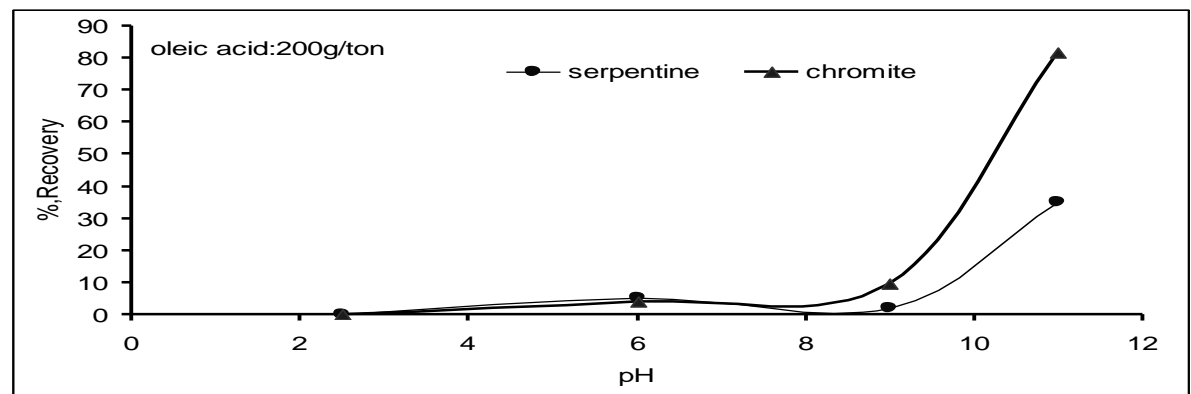

Figure (4): Effect of pH on Recoveries of Chromite and Serpentine at Oleic Acid Conc.200g/t.

Among the various ions that can be present in the pulp, $A l^{3+}$ ions exert the most influence on the flotation behaviour of chromites. These ions cause depression in the $\mathrm{pH}$ range 4.5 to 8 and activation between $\mathrm{pH} 10$ and 12 [Sobierag and Laskowski, 1973]. At pH from 2.5 to 6, there no difference in the floatability between chromite and serpentine. The results depicted of (Fig.5), is agree with that reported by Havens, 1946.

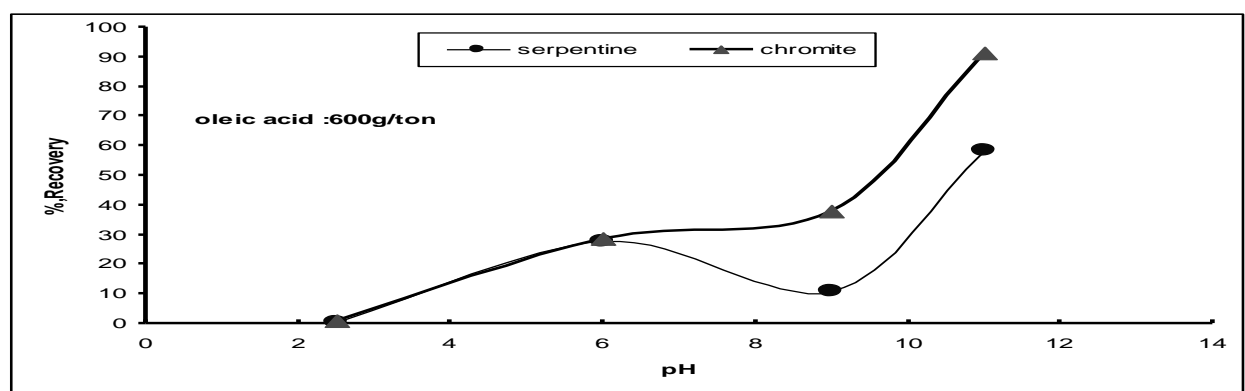

Figure (5): Effect of pH on Recoveries of Chromite and Serpentine at Oleic Acid Conc.600g/t. 


\subsection{Effect of Depressant Concentration}

Figure (6) revealed that the sodium silicate $4 \mathrm{~kg} / \mathrm{t}$ has no significant depressing effect on chromite flotation. However, at $\mathrm{pH} 11$, sodium silicate has some what marked depressing action at $200 \mathrm{~g} / \mathrm{t}$ of oleic acid. It is expected, that a high grade concentrate could be obtained by applying several cleaning stages.

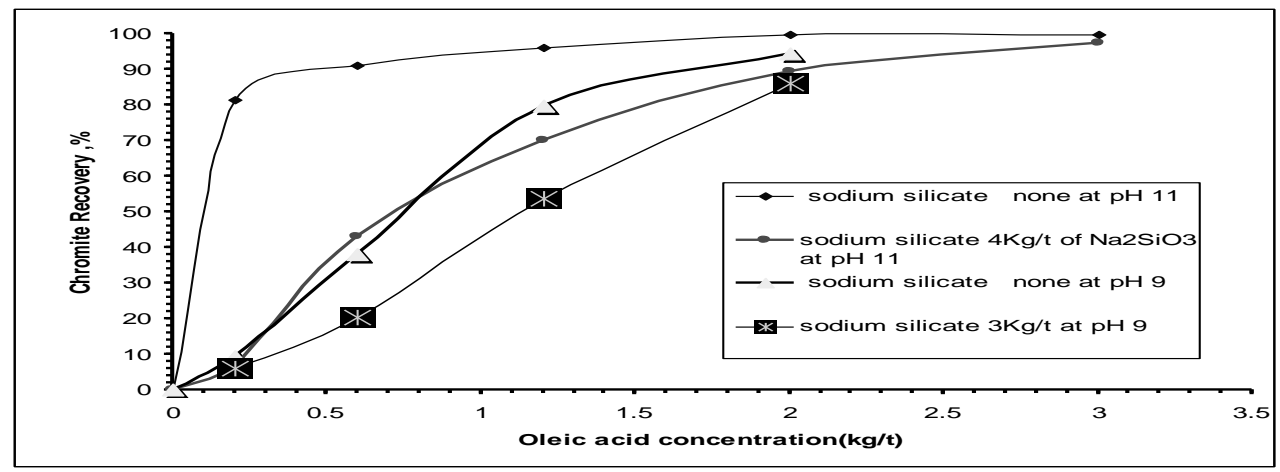

Figure (6): Flotation Recoveries of Chromite as a Function of Various Concentrations of oleic acid in sodium silicate conc. $0 \mathrm{Kg} / \mathrm{t} ; 4 \mathrm{Kg} / \mathrm{t}$ at $\mathrm{pH}$ 9, 11

As silicate concentration increases the flotation recovery of chromite decreases at $\mathrm{pH}$ between 9 to 11 , which indicates the increase of adsorption of silicate at this $\mathrm{pH}$ range. studies of the distribution of various silicate species as a function of $\mathrm{pH}$ have shown that silicic acid , $\mathrm{Si}(\mathrm{OH})_{4}$, and the monosilicate ions $\mathrm{SiO}(\mathrm{OH})_{3}^{-}$, predominate in the $\mathrm{pH}$ range 9 to 10 . 


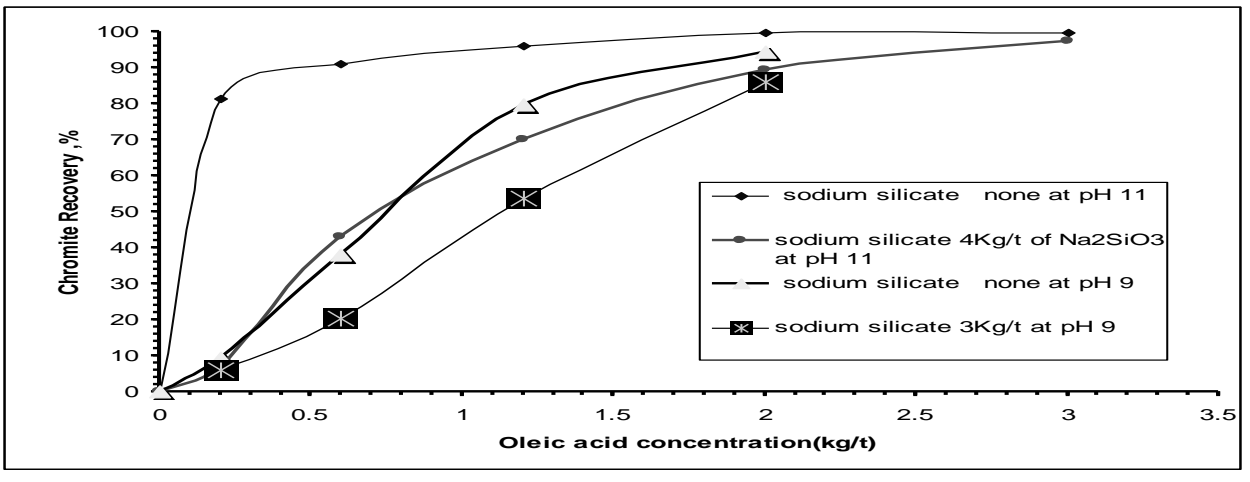

Figure (7): Reveals that the Floatability of Serpentine Decreased as a Result of the Addition of Sodium Silicate. It also Appears from fig. (8) that, at pH 11 the Flotation Recovery Decreased from 58.5\% to $27.55 \%$ as a Result of Addition of $4 \mathrm{~kg} / \mathrm{t}$ Ssodium Silicate

It is stated that, if the mineral surface is covered with highly polymerized silicate, it would be difficult for anionic collectors to adsorb on the surface of mineral and consequently the mineral surface will be strongly depressed. If the mineral surface is covered with monomer silicates or colloidal amorphous silica particles of large size, the coverage will be incomplete and attachment becomes weaker. Therefore, it is less difficult for the oleate to adsorb onto the surface and make the surface hydrophobic.

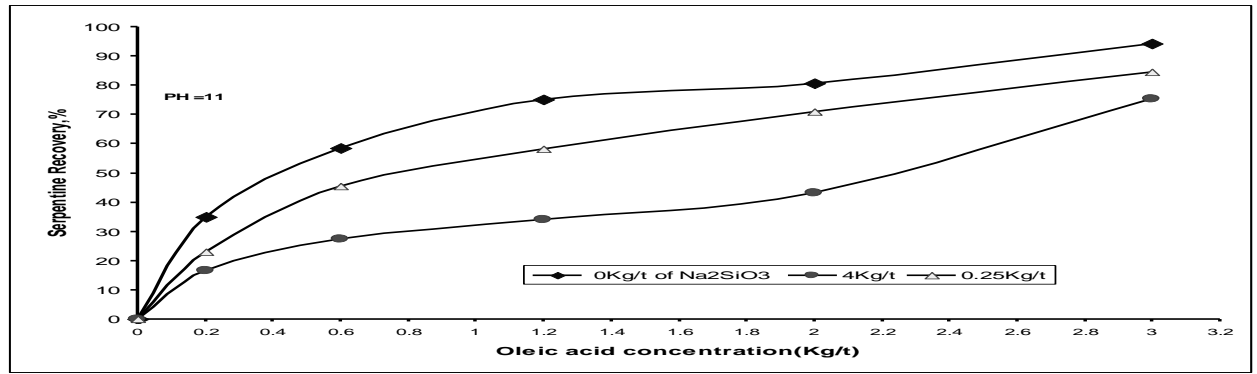

Figure (7): Flotation recoveries of serpentine as a function of various concentrations of oleic acid in sodium silicate conc. $0 \mathrm{Kg} / \mathrm{t} ; 0.25 \mathrm{Kg} / \mathrm{t}$; $4 \mathrm{Kg} / \mathrm{t}$ at $\mathrm{pH} 11$. 


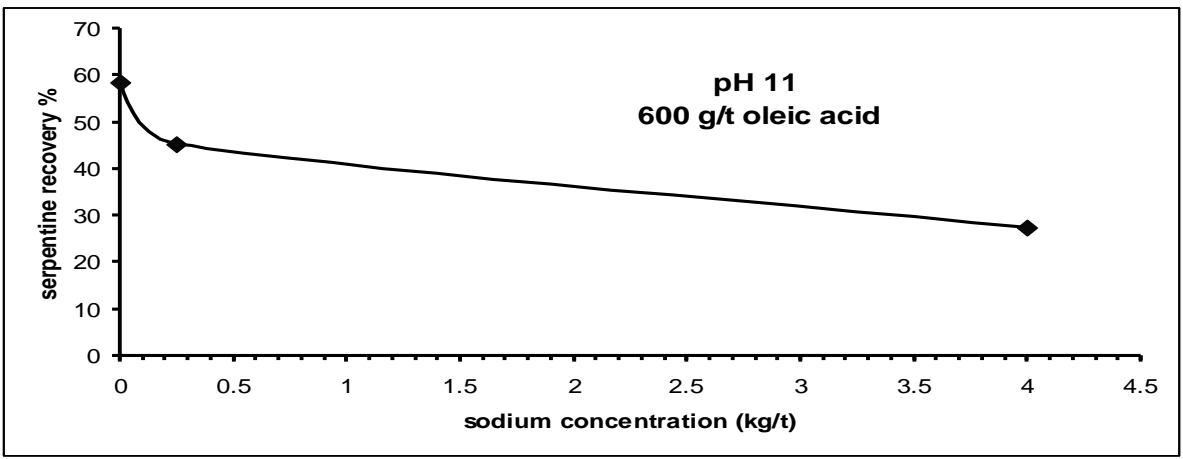

Figure (8): Flotation Recoveries of Serpentine as a Function of Various Concentrations of Sodium Silicate.

Using of sodium silicate $(4 \mathrm{~kg} / \mathrm{t})$ as depressant indicated a somewhat similar effect on flotation behavior of both minerals at $\mathrm{pH} 11,400 \mathrm{~g} / \mathrm{t}$ oleic acid, while increasing oleic acid concentration more than $400 \mathrm{~g} / \mathrm{t}$ increased that difference their floatability markedly (Figure(9)).

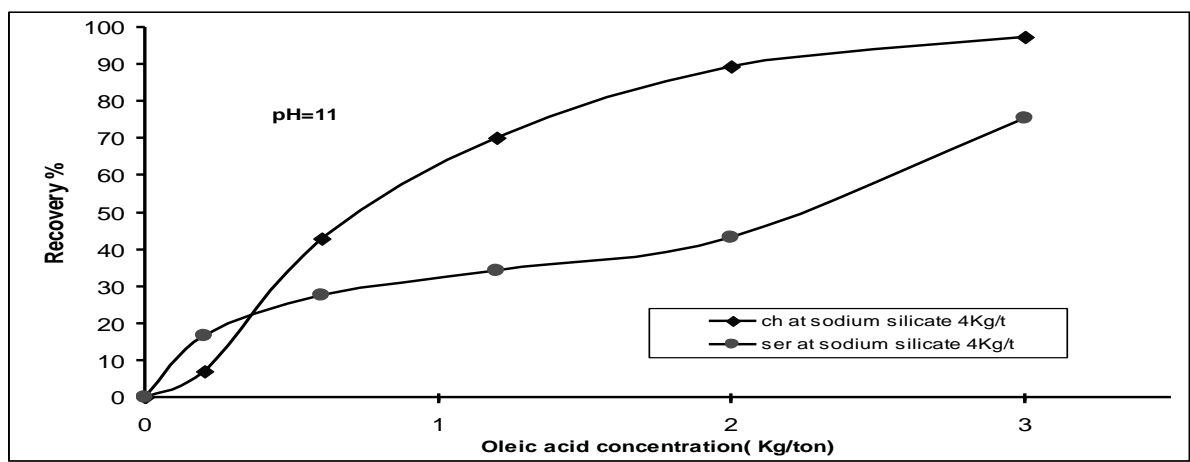

Figure (9): Flotation recoveries of Serpentine and Chromite as a Function of Various Concentrations of Oleic Acid in Sodium Silicate Conc. $4 \mathrm{Kg} / \mathrm{t}$ at pH 11.

\subsection{Influence of Conditioning Time}

Studies to date have revealed that conditioning time plays a very important role in serpentine flotation. Tests conducted to determine the 
influence of conditioning time on flotation behavior of high grade samples yielded some what surprising results. It can seen from figure (10) that the flotation recovery of serpentine increase with increase conditioning time, but chromite remained relatively constant for all conditioning times tested.

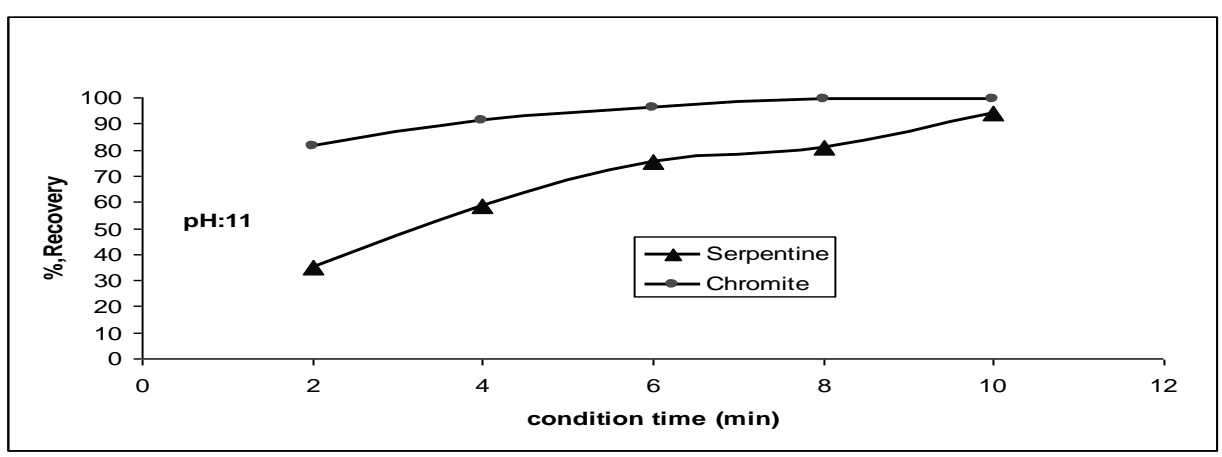

Figure (10): Effect of Conditioning Time on the Flotation Performance of Chromite and serpentine.

\subsection{Flotation of Low Grade Chromite Ore}

The optimum conditions attained from the flotation study concerned with the pure minerals were applied on the flotation of the low grade chromite ore sample.

Low grade chromite ore (containing 20.27\% $\mathrm{Cr}_{2} \mathrm{O}_{3}, \% 100-177 \mu \mathrm{m}$ ) was used in the flotation tests. Flotation tests were conducted in Cominor flotation cell machine with 2-liter capacity.

Flotation test conditions were: Feed size ,100\% -177 $\mu \mathrm{m}$, Pulp density ,20\% solids for conditioning and flotation; Wetting time 5minutes; neutral pH 9 ;Addition of collector (300g/t of Oleic acid);Condition time of collector $2 \mathrm{~min}$; Flotation time $3 \mathrm{~min}$. The results are show in table (4). 
مجلة العلوم الهندسيةـ العددالسادس - 2012

Table (4): Result of Rougher Flotation of Ore Sample \%100 -177 $\mu \mathrm{m}$

\begin{tabular}{|l|c|c|c|c|}
\hline Fraction & weight & weight \% & $\mathbf{C r}_{\mathbf{2}} \mathbf{O}_{\mathbf{3}} \%$ & Recovery \% \\
\hline Floats & 133 & 33.25 & 3.33 & 5.46 \\
\hline Pulp product( sediment) & 267 & 66.75 & 28.71 & 94.54 \\
\hline Feed & 400 & 100.00 & 20.27 & 100.00 \\
\hline
\end{tabular}

The results shown in Table 4 could attributed to the following: metal ions such as $\mathrm{Mg}^{2+}, \mathrm{Ca}^{2+}$, and $\mathrm{Fe}^{3+}$ depress chromite and do not influence serpentine, but the depression of chromite by $\mathrm{Mg}^{2+}$ depends on the anions in the solution. Moreover, the sample contain very fine particle (44.9\% $38 \mu \mathrm{m})$, this cause depression of chromite. It is expected, that a high grade concentrate could be obtained by applying several cleaning stages.

\section{Conclusions}

- Ingassana hills area consists of different chromite deposits assaying $23 \%$ $\mathrm{Cr}_{2} \mathrm{O}_{3}$, which classified as low grade ore. The ore minerals from these deposits were similar in their mineralogical characteristics.

- The major minerals are chromite and serpentine .Olivine, iron oxides and talc have been identified as minor minerals.

- The degree of liberation of chromite minerals from their gangue could be obtained by size reduction to $-0.177 \mathrm{~mm}$.

- Flotation recoveries of chromite and serpentine increased with increasing collector concentration.

- Floatation in alkaline media showed somewhat different floatability characteristics of both chromite and serpentine minerals. 
- Using sodium silicate as depressant indicated a somewhat similar effect on flotation behavior of both minerals.

- The optimum conditioning time of oleic acid was found to be 2 minutes.

- A concentrate of $28.71 \% \mathrm{Cr}_{2} \mathrm{O}_{3}$ with recovery of $94.54 \%$ from a feed assay $20.27 \% \mathrm{Cr}_{2} \mathrm{O}_{3}$ was obtained. . It is expected, that a high grade concentrate could be obtained by applying several cleaning stages.

\section{References}

[1] Havens, R., 1946, Froth flotation of chromite with fluoride. U.S.Patent :2,412,217. pp. 7 (http://www.freepatentsonline.com/4311584.html)

[2] Hunter, W. L., and Sullivan. V., 1960, Utilization studies on chromite from Seiad Creek, Calif. U.S. Bureau of Mines, Report of Investigations 5576 , pp. 37

[3] Koster, J., 1936, Studies on the treatment of domestic chrome ores. U.S. Bureau of Mines, Report of Investigations 3322, pp. 37.

[4] Palmer B. R., Fuerstenau M.C., Aplan F.F., 1975, Mechanism involved in the flotation of oxides and silicates with anionic collectors. Part 2. Trans. AIME, 258, p.261.

[5] Poyor E. J., 1965, Mineral processing, third edition , Amsterdam, London-New York.

[6] Ralph H. Nafziger, 1982, A review of the deposits and beneficiation of lower-grade chromite, Journal of the South African Institute of Mining and Metallurgy, pp. 205-226.

[7] Sagheer, M. 1966. Flotation characteristics of chromite and serpentine. Trans. AIME, vol. 235, no. 1. pp. 60 - 67. 
[8] Shibata J., and Fuerstenau, D.W., 2003, "flocculation and flotation characteristics of fine hematite with sodium oleate", International Journal of Mineral Processing, 72, pp.30

[9] Sobieraj, S. and Laskowski, J., 1973, Flotation of chromite Trans. Instn Min. Metall. Section C, vol. 82, no. 805. pp. C207 - C213. (http://www.freepatentsonline.com/4311584.html). 30/11/2007.

[10] Somasudaran,P., and Wang, Dianzuo ,2006, solution chemistry :minerals and reagents ,Elsevies publisher, Development in mineral processing 17,pp.18-22

[11] U.S. Pat. No. 3,473,6(http://www.freepatentsonline.com/4311584.html) Chem. Absts., 78, 1973, 128755C. 